\title{
Article
}

\section{Inhibition of Diarrheal Shellfish Toxins Accumulation in the Mussel Perna viridis by Curcumin and Underlying Mechanisms}

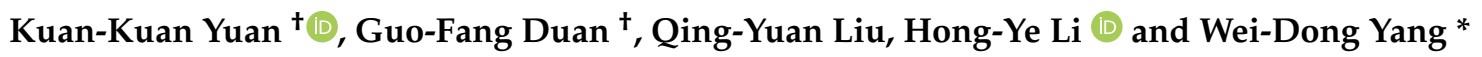 \\ Key Laboratory of Aquatic Eutrophication and Control of Harmful Algal Blooms of Guangdong Higher \\ Education Institute, College of Life Science and Technology, Jinan University, Guangzhou 510632, China; \\ yk9723@stu2019.jnu.edu.cn (K.-K.Y.); dgf1633071004@stu2016.jnu.edu.cn (G.-F.D.); \\ lqy178788@stu2019.jnu.edu.cn (Q.-Y.L.); thyli@jnu.edu.cn (H.-Y.L.) \\ * Correspondence: tywd@jnu.edu.cn \\ † Equal contributors.
}

Citation: Yuan, K.-K.; Duan, G.-F.; Liu, Q.-Y.; Li, H.-Y.; Yang, W.-D. Inhibition of Diarrheal Shellfish Toxins Accumulation in the Mussel Perna viridis by Curcumin and Underlying Mechanisms. Toxins 2021, 13, 578. https://doi.org/10.3390/ toxins 13080578

Received: 3 July 2021

Accepted: 17 August 2021

Published: 20 August 2021

Publisher's Note: MDPI stays neutral with regard to jurisdictional claims in published maps and institutional affiliations.

Copyright: (c) 2021 by the authors. Licensee MDPI, Basel, Switzerland. This article is an open access article distributed under the terms and conditions of the Creative Commons Attribution (CC BY) license (https:// creativecommons.org/licenses/by/ $4.0 /)$.

\begin{abstract}
Diarrheal shellfish toxins (DSTs) are among the most widely distributed phytotoxins, and are associated with diarrheal shellfish poisoning (DSP) events in human beings all over the world. Therefore, it is urgent and necessary to identify an effective method for toxin removal in bivalves. In this paper, we found that curcumin (CUR), a phytopolylphenol pigment, can inhibit the accumulation of DSTs (okadaic acid-eq) in the digestive gland of Perna viridis after Prorocentrum lima exposure. qPCR results demonstrated that CUR inhibited the induction of DSTs on the aryl hydrocarbon receptor (AhR), hormone receptor 96 (HR96) and CYP3A4 mRNA, indicating that the CUR-induced reduction in DSTs may be correlated with the inhibition of transcriptional induction of AhR, HR96 and CYP3A4. The histological examination showed that $P$. lima cells caused severe damage to the digestive gland of $P$. viridis, and the addition of curcumin effectively alleviated the damage induced by P. lima. In conclusion, our findings provide a potential method for the effective removal of toxins from DST-contaminated shellfish.
\end{abstract}

Keywords: DSTs; Perna viridis; AhR; HR96; CYP3A4; CUR

Key Contribution: Curcumin can reduce the accumulation of DST and alleviate the damage of DST to digestive gland of mussels.

\section{Introduction}

Phytotoxin accumulation in filter-feeding shellfish is a global phenomenon. Bivalve mollusks are undoubtedly the main carriers of shellfish toxins, including diarrheal shellfish toxins (DSTs) and paralytic shellfish toxins (PSTs) [1]. Severe poisoning may occur when people consume shellfish that are contaminated with such phytotoxins [2]. DSTs are among the most frequent and globally distributed marine biotoxins, and are usually associated with diarrheal shellfish poisoning (DSP) events all over the world [3-5]. They include okadaic acid (OA) and dinophysis toxins (DTXs). Some genera of Prorocentrum and Dynophysis can produce DSTs [3]. Among them, Prorocentrum lima has been widely used in DST-related studies as a reliable source of DSTs [6].

The main route of human exposure to DSTs is through filter-feeding shellfish. The consumption of these contaminated shellfish may cause food poisoning and obvious gastrointestinal dysfunction, such as diarrhea, abdominal cramps, nausea, vomiting and other symptoms [7,8]. Marine filter feeders such as mussels, oysters, clams, and scallops can accumulate these biotoxins in their tissues, even in environments with a low concentration of DST-producing algal species [9]. More importantly, the properties of these toxins do not change with cooking or freezing, nor do they affect the taste of the contaminated shellfish; thus, they are often difficult to detect without rigorous testing [10,11]. How to effectively reduce the accumulation of toxins in shellfish has attracted widespread 
attention, and various methods for reducing the accumulation of toxins in shellfish have been suggested $[12,13]$. Nevertheless, the safety and feasibility of these methods in practical application are open to question.

Several studies have demonstrated that cytochrome P450 (CYP) may be involved in the metabolism of DSTs [14,15]. Chi et al. observed the OA-caused significant up-regulation of CYP3A4 mRNA in the bay scallop Argopecten irradians [15]. Previously, we found that ketoconazole, an inhibitor of CYP3A4, can decrease OA content in the digestive gland of the mussel Perna viridis [16]. However, ketoconazole may cause certain side effects in humans, limiting its practical use in reducing toxin accumulation [17]. Subsequently, we found that cinnamaldehyde, a compound present in several edible substances, reduced the accumulation of DSTs in mussels, and interestingly, CYP3A4 expression was also significantly down-regulated by cinnamaldehyde in P. lima-exposed mussels [18]. These results suggest that CYP3A4 may be an important participant in the metabolism of DSTs, although the related mechanism remains unclear.

CYP3A4 is transcriptionally regulated by several nuclear receptors, such as the aryl hydrocarbon receptor $(\mathrm{AhR})$, pregnane $\mathrm{X}$ receptor (PXR) and constitutive androstane receptor (CAR) [19]. Numerous studies have shown that AhR is a key regulator of the metabolism of exogenous chemicals in multiple species [20]. Many chemicals can function as ligands to form complexes with $\mathrm{AhR}$, thereby regulating expression of target genes such as CYP1 and many others that are primarily involved in the detoxification and transport of xenobiotics and drugs [21,22]. Zanette et al. found that AhR activators, naphthoflavones and polychlorinated biphenyls induced the expression of CYP3-related genes in the mussel Mytilus edulis [23]. Nuclear receptors, such as PXR, CAR, and vitamin $\mathrm{D}(1,25$-dihydroxyvitamin $\mathrm{D} 3)$ receptor (VDR), can bind to RXR to form a heterodimer, thereby regulating the transcription of CYP3A genes [24]. Hormone receptor 96 (HR96), a presumptive toxicant receptor in the NR1J group of invertebrate nuclear receptors, is evolutionarily closely related to the NR1I (VDR/CAR/PXR) group in mammals [25]. A growing body of research has shown that NR1I group can regulate the expression of phase I, II and III detoxification genes during the metabolism of xenobiotic substances [26-28].

Curcumin (CUR) is a phytopolylphenol pigment isolated from the plant Curcuma longa. As a natural pigment with high safety recognized by Food and Agriculture Organization of the United Nations (FAO) and World Health Organization (WHO), CUR has a variety of anti-inflammatory and anti-cancer properties $[29,30]$. Interestingly, high concentrations of curcumin almost completely inhibited the activity of CYP3A4 in vitro [31]. Some studies have demonstrated that CUR can increase the bioavailability of tamoxifen, probably due to the inhibition of CYP3A4-mediated metabolism of this compound in the small intestine [32]. CUR may also affect the expression of CYP3A4 in shellfish, thereby reducing the toxin accumulation.

To explore whether CUR is able to reduce DST accumulation in bivalve mollusks and to reveal the underlying mechanism, we analyzed the effect of CUR on the accumulation of DSTs in the mussel P. viridis after P. lima exposure under laboratory conditions. The expression, and histological changes in the digestive gland of mussel were observed.

\section{Results}

\subsection{CUR Decreases the Accumulation of DSTs in the Digestive Gland but Not Gills of Mussels}

As shown in Figure 1, the addition of CUR had a great impact on the accumulation of DSTs in the digestive gland of mussel after exposure to P. lima. When the concentrations of CUR were $10 \mu \mathrm{mol} \mathrm{L}{ }^{-1}$ and $20 \mu \mathrm{mol} \mathrm{L}^{-1}$, the DST levels in the digestive gland were significantly lower than that in the control $(p<0.05)$.

Figure 2 demonstrates the DST levels in the digestive gland and in the gills of the P. lima-exposed mussels at different times after the addition of CUR $\left(20 \mu \mathrm{mol} \mathrm{L}^{-1}\right)$. The DST content in the P. lima-exposed mussels was higher than the control counterparts at both 12 and $48 \mathrm{~h}(p<0.05)$. In the digestive gland, the content of DSTs in the P. lima-exposed mussels with CUR was significantly lower than in those without CUR at 12 and $48 \mathrm{~h}$ 
$(p<0.05)$. In contrast, there was no significant difference in the DST content in the gills between the P. lima-exposed mussels with and without CUR.

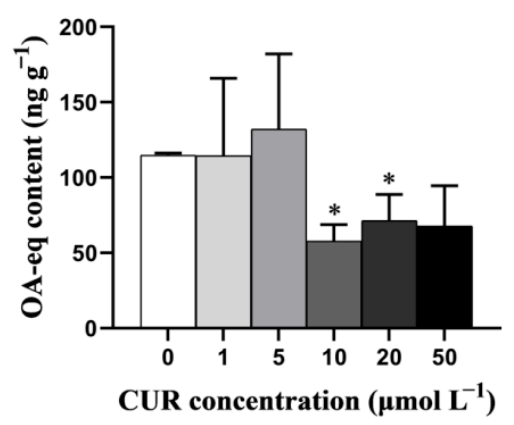

Figure 1. DST content in the digestive gland of the P. lima-exposed mussels with or without curcumin. Significant differences compared to control (with $0 \mu \mathrm{mol} \mathrm{L}{ }^{-1} \mathrm{CUR}$ ) are represented by asterisks $\left(t\right.$-test, $\left.{ }^{*} p<0.05\right)$. Data are presented as mean $\pm \mathrm{SD}(n=3)$.
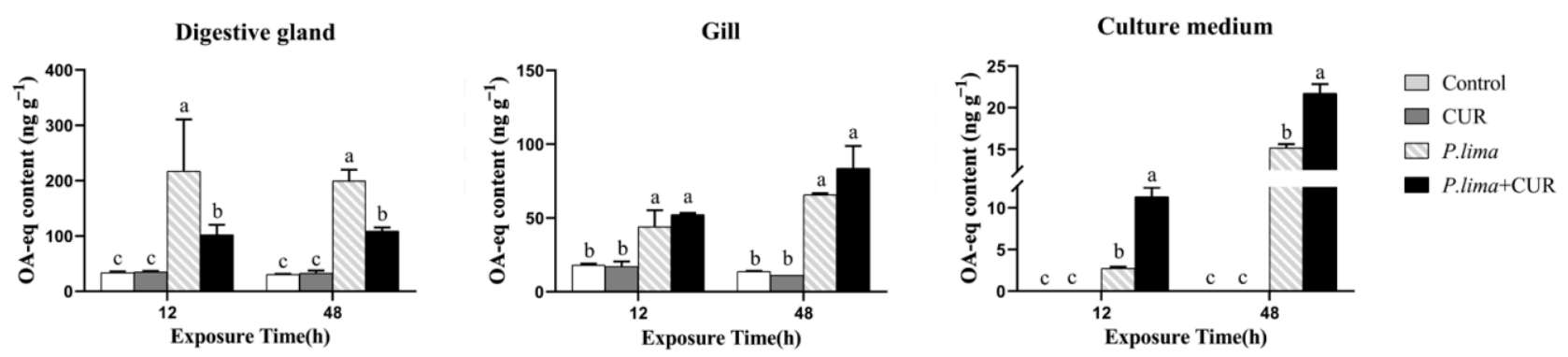

Figure 2. DST content in the digestive gland and gills of the $P$. lima-exposed mussels and in culture medium at different times after the addition of CUR $\left(20 \mu \mathrm{mol} \mathrm{L}{ }^{-1}\right)$. Control, T. subcordiformis $\left(1 \times 10^{7}\right.$ cells/L); CUR, T. subcordiformis $\left(1 \times 10^{7}\right.$ cells/L) + CUR $\left(20 \mu \mathrm{mol} \mathrm{L}{ }^{-1}\right) ;$ P. lima, T. subcordiformis $\left(1 \times 10^{7}\right.$ cells $\left./ \mathrm{L}\right)+$ P. lima $\left(2 \times 10^{6}\right.$ cells $\left./ \mathrm{L}\right) ;$ P. lima + CUR, T. subcordiformis $\left(1 \times 10^{7}\right.$ cells $\left./ \mathrm{L}\right)+P$. lima $\left(2 \times 10^{6}\right.$ cells $\left./ \mathrm{L}\right)+\mathrm{CUR}\left(20 \mu \mathrm{mol} \mathrm{L}{ }^{-1}\right)$. Data are presented as mean $\pm \mathrm{SD}(n=3)$. Bars of the respective treatments followed by the same letters indicates that the difference is not significant at $p<0.05$ (Fisher's protected multiple comparisons LSD test).

To further explore the fate of DSTs in the digestive gland, we measured the level of DSTs in culture medium. As expected, the DST content in the digestive gland was decreased in the P. lima + CUR group at $12 \mathrm{~h}$ and $48 \mathrm{~h}$, while the DST content in culture medium increased compared with the treatment without CUR.

\subsection{CUR Reduced Damage to the Digestive Gland in the P. lima-Exposed Mussels}

Figure 3 shows the histological alterations in the digestive gland after exposure to P. lima with CUR and without CUR. In the control group, the columnar epithelial cells of the digestive diverticulum were neatly arranged, the digestive tubes were interconnected by connective tissue, and there was no atrophy of the epithelial cells. Meanwhile, no significant structural changes were observed in the CUR group. In contrast, the digestive gland tissues in the P. lima-exposed mussels showed significant structural changes (Figure 3C).

At $12 \mathrm{~h}$, the epithelial cells were severely atrophied, some digestive tubules disappeared, and the digestive diverticula formed vacuoles. At $48 \mathrm{~h}$, the epithelium cells displayed more severe atrophy, with partial decomposition of the epithelium, disappearance of the digestive cells, and diverticula deformation of the digestive gland. However, in the P. lima-exposed mussels with curcumin, only mild atrophy of the epithelial cells was observed, and no epithelial cell decomposition was observed. These findings suggest that CUR may effectively alleviate the damage caused by DSTs to the digestive gland in mussels, which might provide new evidence that CUR reduced the accumulation of DSTs in the digestive gland in mussels. 


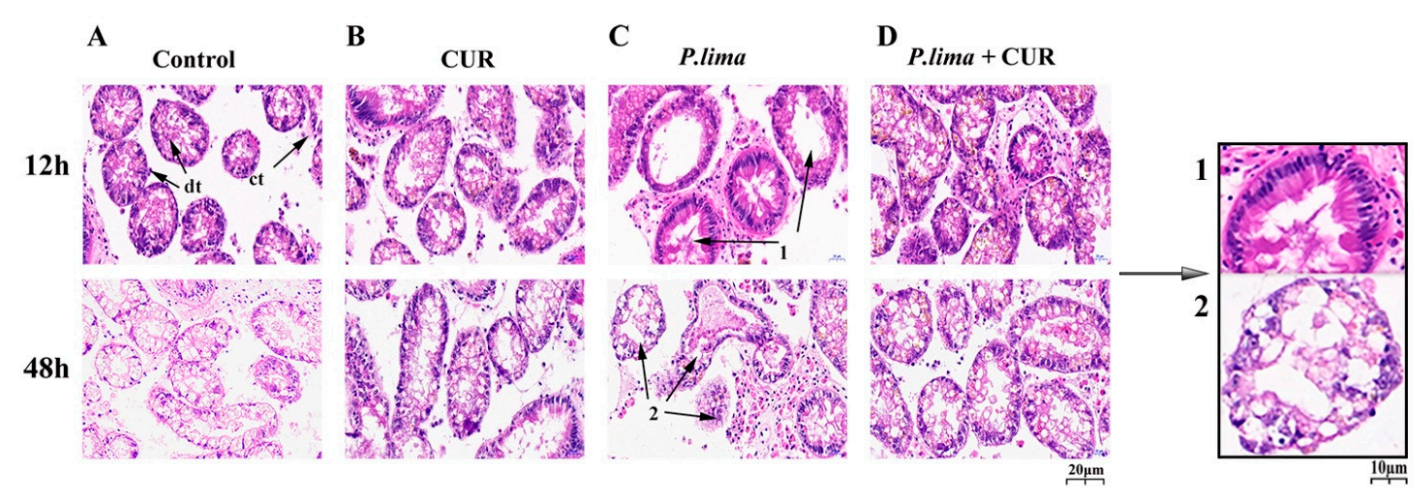

Figure 3. Histological sections of digestive glands of Perna viridis at $12 \mathrm{~h}$ and $48 \mathrm{~h}(\mathrm{HE}$ staining, $\times 400)$. (A) Control, T. subcordiformis $\left(1 \times 10^{7}\right.$ cells $\left./ \mathrm{L}\right)$; (B) CUR, T. subcordiformis $\left(1 \times 10^{7}\right.$ cells $\left./ \mathrm{L}\right)+\mathrm{CUR}(20 \mu \mathrm{mol} \mathrm{L}-1)$; (C) P. lima, T. subcordiformis $\left(1 \times 10^{7}\right.$ cells $\left./ \mathrm{L}\right)+P$. lima $\left(2 \times 10^{6}\right.$ cells $\left./ \mathrm{L}\right)$; (D) P. lima + CUR, T. subcordiformis $\left(1 \times 10^{7}\right.$ cells $\left./ \mathrm{L}\right)+P$. lima $\left(2 \times 10^{6}\right.$ cells $\left./ \mathrm{L}\right)+$ CUR $\left(20 \mu \mathrm{mol} \mathrm{L}{ }^{-1}\right) ; \mathrm{dt}$, alimentary canal; ct, connective tissue. Marker 1 , severe atrophy of epithelial cells; Marker 2, disintegration of epithelial cells, destruction of digestive ducts, and malformation of digestive gland diverticulum.

\subsection{CUR Might Affect the Metabolic Process of DSTs in Mussels by Altering the Expression of Genes Associated with Metabolism}

As illustrated in Figure 4, the expression of CYP3A4 in the P. lima-exposed mussels (P. lima group) was increased compared to the control group $(p<0.05)$ at $48 \mathrm{~h}$. Meanwhile, the expression of AhR at $12 \mathrm{~h}$, and HR96 at $48 \mathrm{~h}$ were significantly up-regulated in the P. lima-exposed mussels compared to the control group $(p<0.05)$. However, after the addition of CUR, CYP3A4 transcription was significantly decreased compared with the counterpart without CUR ( $P$. lima group) at 12 and $48 \mathrm{~h}$. In addition, the expressions of AhR at $12 \mathrm{~h}$, and HR96 at $48 \mathrm{~h}$ after the addition of CUR (P. lima + CUR group) were remarkably lower than those without CUR ( $P$. lima group). These results suggest that CUR may affect the metabolic process of DSTs in mussels by altering the expression of genes involved in metabolism, such as AhR, HR96 and CYP3A4.

AhR

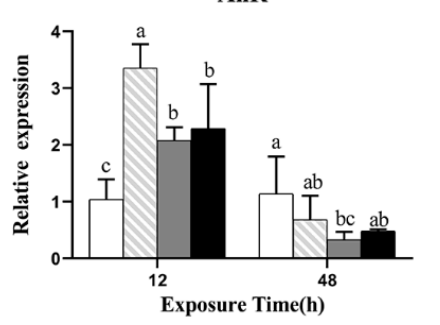

CYP3A4

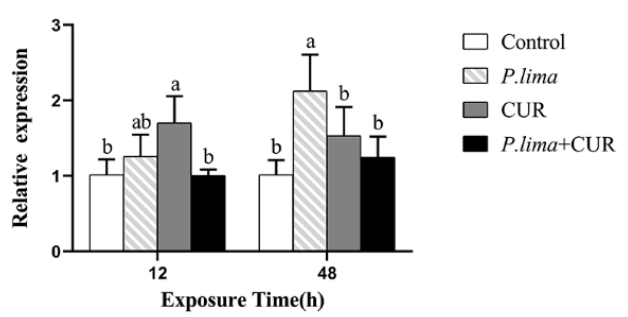

HR96

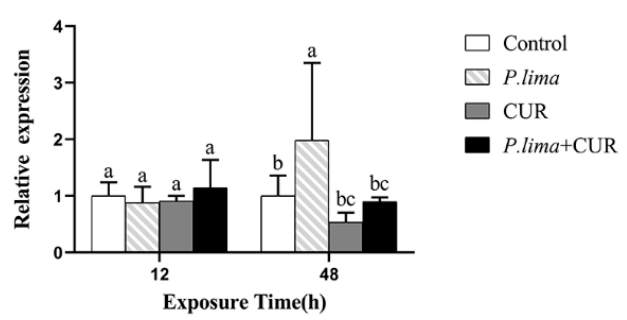

CYP3A1

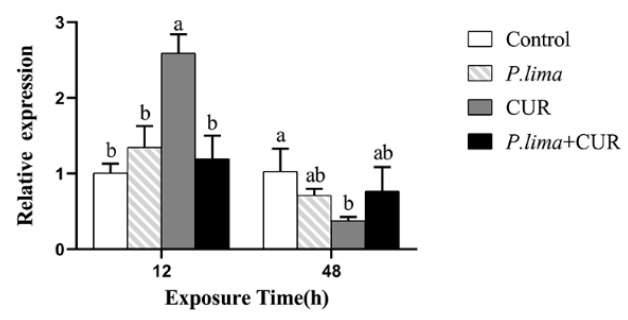

Figure 4. Expression levels of genes associated with the metabolism of xenobiotic compounds in the digestive gland of the P. lima-exposed mussels as shown by qPCR. Control, T. subcordiformis $\left(1 \times 10^{7}\right.$ cells $\left./ \mathrm{L}\right)$; P. lima, T. subcordiformis $\left(1 \times 10^{7}\right.$ cells $\left./ \mathrm{L}\right)+$ P. lima $\left(2 \times 10^{6}\right.$ cells $\left./ \mathrm{L}\right)$; CUR, T. subcordiformis $\left(1 \times 10^{7}\right.$ cells $\left./ \mathrm{L}\right)+\mathrm{CUR}\left(20 \mu \mathrm{mol} \mathrm{L}{ }^{-1}\right) ;$ P. lima + CUR, T. subcordiformis $\left(1 \times 10^{7}\right.$ cells $\left./ \mathrm{L}\right)+P$. lima $\left(2 \times 10^{6}\right.$ cells $\left./ \mathrm{L}\right)+\mathrm{CUR}\left(20 \mu \mathrm{mol} \mathrm{L}{ }^{-1}\right)$. Data presented as mean $\pm \mathrm{SD}(n=3)$. Bars of the respective treatments followed by the same letters indicates that the difference is not significant at $p<0.05$ (Fisher's protected multiple comparisons LSD test). 


\section{Discussion}

At present, a variety of methods to remove shellfish toxins have been proposed, including physical, biological and chemical methods [11,33]. However, these methods are difficult to implement in practice and/or their safety is questionable. Previously, we found that ketoconazole inhibited the expression of CYP3A4, and reduced the OA content in the digestive glands in the P. lima-exposed mussel [16]. Subsequently, we examined the possibility that edible natural substances would reduce the accumulation of DSTs in mussels and found that cinnamaldehyde decreased the accumulation of DSTs in the digestive glands of mussels, and the CYP3A4 transcript was significantly downregulated [18]. The accumulation of DSTs may be related to the expression of CYP3A4, though the underlying mechanism remains unclear.

In the current study, we found that CUR significantly suppressed the accumulation of DSTs in digestive glands of the P. lima-exposed mussels. The histological alteration further demonstrated that CUR effectively alleviated the P. lima-induced damage to the digestive gland. To elucidate the fate of reduced DSTs in the digestive gland after the addition of CUR, we detected the DST content in gills and in culture medium (seawater). In line with our expectation, the DST content in culture medium was increased significantly in the P. lima-exposed group with CUR, while the content of DSTs in gills was not significantly changed. These outcomes suggest that CUR may accelerate the elimination of DSTs rather than transfer them to other tissues.

Histomorphology provides a means to visualize the impact of toxin accumulation on the health of shellfish [34]. Several studies have dealt with the damage caused by DSTs and DST-producing dinoflagellates to bivalves [35,36]. The main lesions in bivalves were tubular atrophy of digestive gland diverticula, the infiltration of hemocyte, the reduction in digestive cells, and the atrophy and decomposition of epithelial cells [35,36]. Consistent with the previous observations, the digestive diverticula in the digestive gland of the $P$. lima-exposed mussel showed tubular atrophy, and the loss of digestive cells resulted in a substantial reduction in epithelial cells. The digestive cells have a well-developed endo-lysosomal system for the digestion of xenobiotic substances [37,38]. Recovery from epithelium atrophy caused by loss of digestive cells is slow or even impossible under natural conditions [39]. However, the addition of CUR effectively prevented the damage caused by DSTs to the digestive gland, which provided new evidence that CUR reduced the accumulation of DSTs in the digestive gland in mussels.

Detoxification in bivalve mollusks is a very complicated process, and cytochrome P450 is involved in the oxygenation of xenobiotic metabolism [40]. Ferron et al. have shown that CYP3A4 mediates the metabolism of lipophilic algal toxins, thereby reducing their in vitro toxicity [41]. The CYP3A proteins in bivalve tissues such as the digestive gland and gills have been demonstrated [42]. Furthermore, some studies have proposed that CYP3A4 might contribute to the metabolism of DSTs in mussels $[15,16,18]$. Interestingly, based on the previous findings $[19,23,43]$, CYP3A4 in bivalves may be transcriptionally regulated by several nuclear receptors such as AhR and HR96. So, we observed the changes in expression of CYP3A4, CYP3A1, AhR and HR96.

We found that the expression of CYP3A4 in the digestive gland was increased at $48 \mathrm{~h}$. Meanwhile, the expression of AhR at $12 \mathrm{~h}$ and $\mathrm{HR} 96$ at $48 \mathrm{~h}$ were significantly up-regulated. However, CYP3A4 transcription in the P. lima-exposed mussel with CUR (P. lima + CUR group) was significantly lower than that without CUR (P. lima group) at both 12 and $48 \mathrm{~h}$, indicating that CUR reduced the expression of CYP3A4 in the digestive gland induced by DSTs. Accordingly, the expressions of AhR and HR96 were significantly decreased in the P. lima-exposed mussels with CUR, and were lower than in mussels without CUR. It is likely that CUR down-regulates the expression of CYP3A4 by suppressing the expression of AhR and HR96 induced by DSTs [44-46]. During the metabolism of DSTs, the expression of AhR was only induced at $12 \mathrm{~h}$ and HR96 was induced at $48 \mathrm{~h}$. The expression of AhR and HR96 seemed to exhibit temporal discontinuity, suggesting that AhR and HR96 may be alternately activated [47]. So far only a few studies have been performed on 
nuclear receptors in shellfish, and very limited information is available on the regulatory effects of nuclear receptors on genes related to detoxification [48,49]. Recent studies have demonstrated that there are great differences between detoxification gene modules in different species [50], and the potential regulatory mechanism needs to be verified in the future.

In this study, curcumin was found to be effective in reducing the accumulation of DSTs in the digestive glands of the P. lima-exposed mussels and in mitigating the damage caused by DSTs to mussels. However, whether it can effectively reduce the accumulation of toxins in actual seawater needs further study. In addition, changes in the expression of CYP3A1 in the presence of curcumin suggests the complexity of curcumin in modulating the metabolism of xenobiotic compounds in shellfish. Therefore, further studies, especially on the removal mechanism, ecological safety and economic cost, should be conducted before attempting to use curcumin to remove toxins in shellfish in field. In addition, the fate of the DSTs from bivalves is indeed an interesting question that deserves further study.

\section{Conclusions}

Curcumin could significantly reduce the accumulation of DSTs in the digestive gland of mussels after P. lima exposure. After exposure to P. lima, CYP3A4, AhR and HR96 were expressed in the digestive gland of mussels, while CUR inhibited the overexpression. It is likely that CUR could down-regulate the expression of CYP3A4 by suppressing the expression of AhR and HR96. These may lead to changes in the metabolic process of DSTs in vivo, and ultimately reduce the accumulation of toxins in the digestive glands of P. lima-exposed mussels; thus, effectively ameliorating the damage to the digestive gland. However, the removal mechanism remains largely unclear, especially the exact role of CYP3A4, which needs further study.

\section{Materials and Methods}

\subsection{Materials and Animals}

The mussel P. viridis used in the experiment was purchased from the Huangsha Aquatic Products Market in Guangzhou, and the mussels were collected from the Zhanjiang Sea area, China. P. viridis individuals with a length of 8 to $10 \mathrm{~cm}$ and a total soft body weight of $12.4 \pm 1 \mathrm{~g}$ were chosen and transported to our laboratory as quickly as possible under low temperature. After the mud on the shell surface was removed, the cleaned animals were cultured in several aerated glass tanks $(45 \mathrm{~cm} \times 30 \mathrm{~cm} \times 35 \mathrm{~cm})$ under controlled conditions $\left(17.5 \pm 1{ }^{\circ} \mathrm{C}, 12 \mathrm{~h}\right.$ light $/ 12 \mathrm{~h}$ dark cycle). The natural seawater with a salinity of $35 \pm 2$, was changed regularly every day, and the chlorophyte Tetraselmis subcordiformis $\left(1 \times 10^{7}\right.$ cells $\left./ \mathrm{L}\right)$ was used to feed the mussels. Animals with good growth and strong foot silk were selected for the experiments.

The chlorophyte T. subcordiformis used in the experiment was kindly provided by the Institute of Hydrobiology, Chinese Academy of Sciences. As in previous studies, the DST-producing dinoflagellate P. lima (CCMP 2579), which has been proved to produce OA and DTX1 [51,52], was purchased from the National Center for Marine Algae and Microbiology (NCMA) (https://ncma.bigelow.org, Accessed on 17 August 2021). The two algal species were cultured in $\mathrm{f} / 2$ silicon-free medium, which was filtered through a $0.22 \mu \mathrm{m}$ filter. The cultures were grown at $20 \pm 1{ }^{\circ} \mathrm{C}$ in an artificial climate incubator (Ningbo Jiangnan Instrument Factory, China) $\left(60 \mu \mathrm{mol} \mathrm{m} \mathrm{m}^{-2} \mathrm{~s}^{-1}, 12 \mathrm{~h} / 12 \mathrm{~h}\right.$ photoperiod).

Curcumin (purity $\geq 94 \%$ ) purchased from Sigma-Aldrich (C7727, Germany), was dissolved in $0.5 \mathrm{~mol} \mathrm{~L}^{-1} \mathrm{NaOH}$ solution to a concentration of $200 \mathrm{mmol} \mathrm{L}^{-1}$, and then diluted to $80 \mathrm{mmol} \mathrm{L}^{-1}$ with natural seawater [53].

\subsection{Experimental Design}

Given that DSTs are mainly concentrated in the digestive gland of mussels [54], we focused on the DSTs content in digestive gland tissue of the P. lima-exposed P. viridis. Our experiment was divided into two steps: 
Step I: Changes in DSTs content (OA-eq) after the addition of CUR. The P. viridis individuals were fed with $1 \times 10^{7}$ cells/L of T. subcordiformis and $2 \times 10^{6}$ cells/L of P. lima for $2 \mathrm{~h}$, CUR was added to the culture medium $(6 \mathrm{~L})$ with different final concentrations $(0,1$, $5,10,20,50 \mu \mathrm{mol} \mathrm{L}-1$, respectively). All digestive gland tissues with a weight of about $0.1 \mathrm{~g}$ were collected from each animal at $48 \mathrm{~h}$ after the addition of CUR or solvent. To reduce the individual differences, tissues from six individual mussels within the same group were pooled together as one sample for the detection of DSTs. Therefore, each treatment group had three samples, each of which contained six individual mussels.

Step II: Alterations in the DST content in mussels after exposure to P. lima for different times with or without CUR. The mussel $P$. viridis individuals were randomly divided into four groups as follows: (1) Control, T. subcordiformis $\left(1 \times 10^{7}\right.$ cells/L); (2) CUR, T. subcordiformis $\left(1 \times 10^{7}\right.$ cells $\left./ \mathrm{L}\right)+$ CUR $\left(20 \mu \mathrm{mol} \mathrm{L}{ }^{-1}\right)$; (3) P. lima, T. subcordiformis $\left(1 \times 10^{7}\right.$ cells $\left./ \mathrm{L}\right)+$ P. lima $\left(2 \times 10^{6}\right.$ cells $\left./ \mathrm{L}\right)$; (4) P. lima + CUR, T. subcordiformis $\left(1 \times 10^{7}\right.$ cells $\left./ \mathrm{L}\right)+P$. lima $\left(2 \times 10^{6}\right.$ cells $\left./ \mathrm{L}\right)+$ CUR $\left(20 \mu \mathrm{mol} \mathrm{L}{ }^{-1}\right)$. In terms of design, the final concentration of $20 \mu \mathrm{mol} \mathrm{L}{ }^{-1}$ CUR was added into culture medium at $2 \mathrm{~h}$ after $1 \times 10^{7}$ cells / $L$ of T. subcordiformis and $2 \times 10^{6}$ cells / L of P. lima were added. The control group and $P$. lima group was added with isovolumetric solvent (mixture of $600 \mu \mathrm{L}$ of $0.5 \mathrm{~mol} \mathrm{~L}^{-1} \mathrm{NaOH}$ and $900 \mu \mathrm{L}$ of seawater). For the histological examination, digestive gland tissues were sampled at 12 and $48 \mathrm{~h}$ after the addition of CUR. At $12 \mathrm{~h}$ and $48 \mathrm{~h}$ after the addition of CUR, eighteen individuals were randomly sampled at each time point in each treatment. Gills and digestive gland with a weight of about $0.1 \mathrm{~g} /$ individual were excised, and tissue from six individuals at each time point within the same treatment were pooled together as one sample for DSTs (stored in $-20^{\circ} \mathrm{C}$ freezer) and total RNA extraction (stored in $-80^{\circ} \mathrm{C}$ freezer). In addition, culture medium (seawater sample) was collected at $12 \mathrm{~h}$ and $48 \mathrm{~h}$ (stored in $4^{\circ} \mathrm{C}$ freezer).

\subsection{Detection of DSTs}

DST extraction and detection in shellfish and culture medium was performed as per our previous paper [16]. An okadaic acid (DSP) ELISA test kit (Abraxis, Warminster, PA, USA) was used, in which the absorbance at $450 \mathrm{~nm}$ was detected by a Synergy H1 Hybrid Multi-Mode Microplate Reader (Bio-Tek, Winooski, VT, USA). The OA content was calculated according to the standard curve generated and expressed as ng OA eq $\mathrm{g}^{-1}$.

The DST content in the culture medium was measured using an Oasis HLB 6 cC (500 mg) LP Extraction Cartridge (Waters Ltd., Worcester, MA, USA) filter column as described by Fang et al. with slight modifications [55], in which a Supelco Visiprep 12 tube anti-contamination (DL) solid phase extraction unit was used. Briefly, the HLB filter column was firstly activated with methanol, and washed with distilled water. Then, $30 \mathrm{~mL}$ of culture medium sample was added to the HLB filter column. The column was eluted successively with $3 \mathrm{~mL} \mathrm{100 \%} \mathrm{methanol} \mathrm{and} 2 \mathrm{~mL} \mathrm{30 \%} \mathrm{methanol.} \mathrm{The} \mathrm{collected} \mathrm{eluent} \mathrm{was}$ dried with nitrogen and dissolved in $500 \mu \mathrm{L}$ of methanol for DST detection. DST detection was carried out via ELISA as above.

\section{4. $q P C R$}

Total RNA was extracted from an approximately $50 \mathrm{mg}$ sample of mussel tissue by using a Total RNA Kit I (50) R6934-01 (Omega, Norcross, GA, USA). RNA integrity and genome DNA contamination were tested by a denaturing agarose gel electrophoresis. RNA concentration was measured using a NanoDrop 2000 Spectrophotometer at $260 \mathrm{~nm}$ (Implen, Munich, Germany). Approximately $1 \mu \mathrm{g}$ of total RNA was reverse transcribed using a HiScript ${ }^{\circledR}$ II Q RT SuperMix for qPCR (+gDNA wiper) (R223-01, Vazyme, Nanjing, China) kit according to the manufacturer's instructions.

The most stable genes, RPL3 and RPL13 were used as reference genes to normalize the expression of target genes including AhR, HR96, CYP3A4 and CYP3A1. The expression of five candidate genes including elongation factor 1 alpha $(\mathrm{EF} 1 \alpha)$, ribosomal protein L3 (RPL3), ribosomal protein L13-like (RPL13), ribosomal protein L37 (RPL37) and ubiquitin A- 
52 (UBA52) was examined for screening reference genes. Three kinds of software including geNorm [56], NormFinder [57] and BestKepper [58] were employed. All the primers were designed based on the sequences of Mytilus edulis by using Primer 5.0 software (Premier, Waterloo, ON, Canada) according to the following parameters: ideal melting temperature (Tm), GC content, length, and amplicon length (Table 1).

Table 1. Primer for qPCR.

\begin{tabular}{|c|c|c|c|}
\hline Gene Name & & Primer Sequence $\left(5^{\prime}-3^{\prime}\right)$ & Amplicon Size (bp) \\
\hline \multirow[b]{2}{*}{$\mathrm{EF} 1-\mathrm{F} \alpha$} & F: & CACTCCGTCTTCCACTCCA & \multirow[b]{2}{*}{131} \\
\hline & $\mathrm{R}:$ & CCTCTGGCATTGACTCGTG & \\
\hline \multirow{2}{*}{ Tubulin- $\beta$} & F: & AGGAAGGAGGCTGAGAGTTGT & \multirow{2}{*}{135} \\
\hline & $\mathrm{R}:$ & TTTGGAGATGAGCAGGGTTC & \\
\hline \multirow{2}{*}{ RPL3 } & F: & GGTGGCACTATCTCCCAGAA & \multirow{2}{*}{98} \\
\hline & $\mathrm{R}:$ & GCCATCTGGACGTTACACCT & \\
\hline \multirow{2}{*}{ UBA52 } & F: & TTACATTTGGTCCTGCGTCTC & \multirow{2}{*}{135} \\
\hline & $\mathrm{R}:$ & CAGTTGGTAGCCCTTTGATGA & \\
\hline \multirow{2}{*}{ RPL13 } & $\mathrm{F}:$ & TAAAGACTGGCAACGCTATGT & \multirow{2}{*}{155} \\
\hline & $\mathrm{R}:$ & TCACAACTGGTCGGAGAAG & \\
\hline \multirow{2}{*}{ RPL37 } & F: & GTCGCAATAAGACGCACACGTTG & \multirow{2}{*}{179} \\
\hline & $\mathrm{R}:$ & GTGCCTCATTCGACCAGTTCCG & \\
\hline \multirow{2}{*}{ AhR } & F: & GAGAGTTCTGGAGTGTTCGTGGAC & \multirow{2}{*}{109} \\
\hline & R: & TGAGGACACGGTTCAGTCAG & \\
\hline \multirow{2}{*}{ HR96 } & F: & TGGAGCCTGATGAAGAATACC & \multirow{2}{*}{194} \\
\hline & $\mathrm{R}:$ & ACTGAGAGAGAGCCTTGAATG & \\
\hline \multirow{2}{*}{ CYP3A4 } & F: & ACCAATGCAAATGCGTGGTC & \multirow{2}{*}{99} \\
\hline & $\mathrm{R}:$ & TCAGCAGGCAGTATTCCAGGAGAG & \\
\hline \multirow{2}{*}{ CYP3A1 } & $\mathrm{F}:$ & CGCTGCTGTGACGATCTGGTAG & \multirow{2}{*}{141} \\
\hline & $\mathrm{R}:$ & TCTCTGCGAATTCACCTGCAACC & \\
\hline
\end{tabular}

EF1 $\alpha$, elongation factor 1 alpha; RPL3, ribosomal protein L3; RPL13, ribosomal protein L13-like; RPL37, ribosomal protein L37; UBA52, ubiquitin A-52; CYP3A1, Cytochrome P450 3A1; CYP3A4, Cytochrome P450 3A4. AhR, Aryl hydrocarbon receptor; HR96, Nuclear hormone receptor 96.

PCR was performed on a CFX96 Real-Time PCR System (Bio-Rad, Hercules, CA, USA) using AceQ ${ }^{\circledR}$ qPCR SYBR ${ }^{\circledR}$ Green Master Mix (Vazyme, Nanjing, China) with the following profile: $95^{\circ} \mathrm{C}$ for $5 \mathrm{~min}, 40$ cycles of $95^{\circ} \mathrm{C}$ for $10 \mathrm{~s}, 60^{\circ} \mathrm{C}$ for $30 \mathrm{~s}$. PCR specificity was evaluated by melting curve analysis from $65^{\circ} \mathrm{C}$ to $95^{\circ} \mathrm{C}$, increasing by $0.5^{\circ} \mathrm{C}$ every $5 \mathrm{~s}$. The reaction mixture $(20 \mu \mathrm{L})$ consisted of $10 \mu \mathrm{L}$ of AceQ ${ }^{\circledR}$ qPCR SYBR ${ }^{\circledR}$ Green Master Mix, $7.6 \mu \mathrm{L}$ of $\mathrm{H}_{2} \mathrm{O}, 0.2 \mu \mathrm{L}$ of each of the forward and reverse primers $\left(10 \mu \mathrm{mol} \mathrm{L}^{-1}\right)$ and $2 \mu \mathrm{L}$ of the first-strand cDNA template from $1 \mu \mathrm{g}$ RNA. Amplification was also performed on equivalent double-distilled water as no template control (NTC) to check the absence of contaminant. The inter-run calibrator (IRC) was set to eliminate errors in running data for the two boards. The amplification efficiency of all genes assayed was guaranteed to be between $98 \%$ and $105 \%$, and the correlation coefficient was 0.99 .

The comparative $\mathrm{C}_{\mathrm{q}}$ method was used to analyze relative expression level of genes as described by Derveaux et al., where multiple reference genes and inter-run calibration algorithms were considered [59].

\subsection{Histological Examination}

Histological examination was performed as described by previous reports with some modifications [35]. Briefly, digestive gland tissue dissected from animals was fixed in $4 \%$ paraformaldehyde solution for at least $48 \mathrm{~h}$. Subsequently, the tissue was dehydrated in gradient ethanol solutions (from $75 \%$ to $95 \%$ ), then embedded in paraffin. The embedded tissue was sectioned at $4 \mu \mathrm{m}$ thickness with a manual rotary microtome (Leica 
RM2235, Lecia Microsystems Nussloch Gmbh, Heidelberger, Germany). The paraffinembedded section obtained was deparaffinized in xylene, rehydrated in gradient ethanol solutions, and then stained with hematoxylin and eosin. After each sample was sealed with neutral balsam, the stained slice was imaged using a Panoramic MIDI Slide Scanner (3DHISTECH, Budapest, Hungary), and analyzed by Case-Viewer software (3DHISTECH, Budapest, Hungary).

\subsection{Statistical Analyses}

Statistical analyses were conducted by using SPSS Statistics 25.0 for Windows (IBM SPSS Statistics 25.0 Packet program, Arnomk, NY, USA) (https:/ / www.ibm.com/cn-zh, Accessed on 17 August 2021.) All data were expressed as mean \pm SD. In Step I, the difference in DST content between two groups was examined by $t$-test. In Step II, differences between treatment groups were estimated by Fisher's protected multiple comparisons least significant difference (LSD) test with a significant difference at $p<0.05$.

Author Contributions: K.-K.Y.: methodology, validation, visualization. G.-F.D.: methodology, formal analysis, writing — original draft, methodology. Q.-Y.L.: methodology. H.-Y.L.: methodology, supervision. W.-D.Y.: methodology, conceptualization, supervision, writing-review \& editing. All authors have read and agreed to the published version of the manuscript.

Funding: This work was funded by the National Key Research and Development Program of China (2019YFC0312600), National Natural Science Foundation of China (42076143, 41776120, 41576116).

Institutional Review Board Statement: Not applicable.

Informed Consent Statement: Not applicable.

Data Availability Statement: The data in this study are available from the corresponding author upon request.

Conflicts of Interest: The authors declare no conflict of interest.

\section{References}

1. Shumway, S.E. A review of the effects of algal blooms on shellfish andaquaculture. J. World Aquacult. Soc. 1990, 21, 65-104. [CrossRef]

2. Gerssen, A.; Pol-Hofstad, I.E.; Poelman, M.; Mulder, P.P.; Van den Top, H.J.; De Boer, J. Marine toxins: Chemistry, toxicity, occurrence and detection, with special reference to the Dutch situation. Toxins 2010, 2, 878-904. [CrossRef] [PubMed]

3. Chen, T.; Xu, X.; Wei, J.; Chen, J.; Miu, R.; Huang, L.; Zhou, X.; Fu, Y.; Yan, R.; Wang, Z.; et al. Food-borne disease outbreak of diarrhetic shellfish poisoning due to toxic mussel consumption: The first recorded outbreak in China. PLoS ONE 2013, 8, e65049. [CrossRef] [PubMed]

4. Taylor, M.; McIntyre, L.; Ritson, M.; Stone, J.; Bronson, R.; Bitzikos, O.; Rourke, W.; Galanis, E.; Outbreak Investigation, T. Outbreak of diarrhetic shellfish poisoning associated with mussels, British Columbia, Canada. Mar. Drugs 2013, 11, 1669-1676. [CrossRef] [PubMed]

5. Reguera, B.; Velo-Suárez, L.; Raine, R.; Park, M.G. Harmful Dinophysis species: A review. Harmful Algae 2012, 14, 87-106. [CrossRef]

6. Nascimento, S.M.; Purdie, D.A.; Morris, S. Morphology, toxin composition and pigment content of Prorocentrum lima strains isolated from a coastal lagoon in southern UK. Toxicon 2005, 45, 633-649. [CrossRef]

7. Kamat, P.K.; Rai, S.; Nath, C. Okadaic acid induced neurotoxicity: An emerging tool to study Alzheimer's disease pathology. Neurotoxicology 2013, 37, 163-172. [CrossRef]

8. Ma, J.; Li, J.H.; Hao, Y.M.; Nie, Y.Z.; Li, Z.S.; Qian, M.R.; Liang, Q.Y.; Yu, J.; Zeng, M.S.; Wu, K.C. Differentiated tumor immune microenvironment of Epstein-Barr virus-associated and negative gastric cancer: Implication in prognosis and immunotherapy. Oncotarget 2017, 8, 67094-67103. [CrossRef]

9. Bernard, F.R. Uptake and elimination of coliform bacteria by four marine bivalve mollusks. Can. J. Fish. Aquat. Sci. 1989, 46, 1592-1599. [CrossRef]

10. McCarron, P.; Kilcoyne, J.; Hess, P. Effects of cooking and heat treatment on concentration and tissue distribution of okadaic acid and dinophysistoxin-2 in mussels (Mytilus edulis). Toxicon 2008, 51, 1081-1089. [CrossRef]

11. Reboreda, A.; Lago, J.; Chapela, M.J.; Vieites, J.M.; Botana, L.M.; Alfonso, A.; Cabado, A.G. Decrease of marine toxin content in bivalves by industrial processes. Toxicon 2010, 55, 235-243. [CrossRef] 
12. Blanco, J.; Arévalo, F.; Correa, J.; Porro, M.C.; Cabado, A.G.; Vieites, J.M.; Moroño, A. Effect of the industrial steaming on the toxicity, estimated by LC-MS/MS, of mussels exposed for a long time to diarrhetic shellfish poisoning (DSP) toxins. Food Chem. 2015, 177, 240-247. [CrossRef] [PubMed]

13. Qiu, J.; Fan, H.; Liu, T.; Liang, X.; Meng, F.; Quilliam, M.A.; Li, A. Application of activated carbon to accelerate detoxification of paralytic shellfish toxins from mussels Mytilus galloprovincialis and scallops Chlamys farreri. Ecotoxicol. Environ. Saf. 2018, 148, 402-409. [CrossRef] [PubMed]

14. Vidal, A.; Ruiz, Y.; Suárez, P.; Martinez, A.A.; Rossignoli, A.; Blanco, J.; Garcia, O.; San Juan, F. Accumulation of okadaic acid and detoxifying enzymes in the digestive gland of Mytilus galloprovincialis during exposure to DSP. In Molluscan Shellfish Safety; Springer: Berlin/Heidelberg, Germany, 2014; pp. 217-225.

15. Chi, C.; Giri, S.S.; Jun, J.W.; Kim, S.W.; Kim, H.J.; Kang, J.W.; Park, S.C. Detoxification- and immune-related transcriptomic analysis of gills from bay scallops (Argopectenirradians) in response to algal toxin okadaic acid. Toxins 2018, 10, 308. [CrossRef]

16. Wei, X.M.; Lu, M.Y.; Duan, G.F.; Li, H.Y.; Liu, J.S.; Yang, W.D. Responses of CYP450 in the mussel Perna viridis after short-term exposure to the DSP toxins-producing dinoflagellate Prorocentrum lima. Ecotoxicol. Environ. Saf. 2019, 176, 178-185. [CrossRef]

17. Gupta, A.K.; Lyons, D.C. The rise and fall of oral ketoconazole. J. Cutan. Med. Surg. 2015, 19, 352-357. [CrossRef] [PubMed]

18. Duan, G.F.; Liu, Y.; Zhang, L.N.; Li, H.Y.; Liu, J.S.; Yang, W.D. Cinnamaldehyde could reduce the accumulation of diarrhetic shellfish toxins in the digestive gland of the mussel Perna viridis under laboratory conditions. Mar. Drugs 2021, 19, 63. [CrossRef] [PubMed]

19. Du, Z.H.; Xia, J.; Sun, X.C.; Li, X.N.; Zhang, C.; Zhao, H.S.; Zhu, S.Y.; Li, J.L. A novel nuclear xenobiotic receptors (AhR/PXR/CAR)mediated mechanism of DEHP-induced cerebellar toxicity in quails (Coturnix japonica) via disrupting CYP enzyme system homeostasis. Environ. Pollut. 2017, 226, 435-443. [CrossRef] [PubMed]

20. Sun, Y.V.; Boverhof, D.R.; Burgoon, L.D.; Fielden, M.R.; Zacharewski, T.R. Comparative analysis of dioxin response elements in human, mouse and rat genomic sequences. Nucleic Acids Res. 2004, 32, 4512-4523. [CrossRef]

21. Esser, C.; Rannug, A. The aryl hydrocarbon receptor in barrier organ physiology, immunology, and toxicology. Pharmacol. Rev. 2015, 67, 259-279. [CrossRef]

22. Islam, J.; Sato, S.; Watanabe, K.; Watanabe, T.; Ardiansyah; Hirahara, K.; Aoyama, Y.; Tomita, S.; Aso, H.; Komai, M.; et al. Dietary tryptophan alleviates dextran sodium sulfate-induced colitis through aryl hydrocarbon receptor in mice. J. Nutr. Biochem. 2017, 42, 43-50. [CrossRef]

23. Zanette, J.; Jenny, M.J.; Goldstone, J.V.; Parente, T.; Woodin, B.R.; Bainy, A.C.; Stegeman, J.J. Identification and expression of multiple CYP1-like and CYP3-like genes in the bivalve mollusk Mytilus edulis. Aquat. Toxicol. 2013, 128-129, 101-112. [CrossRef]

24. Chen, S.; Wang, K.; Wan, Y.J. Retinoids activate RXR/CAR-mediated pathway and induce CYP3A. Biochem. Pharmacol. 2010, 79, 270-276. [CrossRef]

25. Bertrand, S.; Brunet, F.G.; Escriva, H.; Parmentier, G.; Laudet, V.; Robinson-Rechavi, M. Evolutionary genomics of nuclear receptors: From twenty-five ancestral genes to derived endocrine systems. Mol. Biol. Evol. 2004, 21, 1923-1937. [CrossRef]

26. Hernandez, J.P.; Mota, L.C.; Baldwin, W.S. Activation of CAR and PXR by dietary, environmental and occupational chemicals alters drug metabolism, intermediary metabolism, and cell proliferation. Curr. Pharmacogenom. Person Med. 2009, 7, 81-105. [CrossRef] [PubMed]

27. Cruzeiro, C.; Lopes-Marques, M.; Ruivo, R.; Rodrigues-Oliveira, N.; Santos, M.M.; Rocha, M.J.; Rocha, E.; Castro, L.F. A mollusk VDR/PXR/CAR-like (NR1J) nuclear receptor provides insight into ancient detoxification mechanisms. Aquat. Toxicol. 2016, 174, 61-69. [CrossRef] [PubMed]

28. Oladimeji, P.O.; Chen, T.S. PXR: More than just a master xenobiotic receptor. Mol. Pharmacol. 2018, 93, 119-127. [CrossRef] [PubMed]

29. Sharma, R.A.; Gescher, A.J.; Steward, W.P. Curcumin: The story so far. Eur. J. Cancer 2005, 41, 1955-1968. [CrossRef]

30. Zhou, H.; Beevers, C.S.; Huang, S. The targets of curcumin. Curr. Drug Targets 2011, 12, 332-347. [CrossRef]

31. Appiah-Opong, R.; Commandeur, J.N.; van Vugt-Lussenburg, B.; Vermeulen, N.P. Inhibition of human recombinant cytochrome P450s by curcumin and curcumin decomposition products. Toxicology 2007, 235, 83-91. [CrossRef]

32. Cho, Y.A.; Lee, W.; Choi, J.S. Effects of curcumin on the pharmacokinetics of tamoxifen and its active metabolite, 4hydroxytamoxifen, in rats: Possible role of CYP3A4 and P-glycoprotein inhibition by curcumin. Pharmazie 2012, 67, 124-130. [CrossRef] [PubMed]

33. Xie, W.C.; Liu, X.L.; Yang, X.H.; Zhang, C.H.; Bian, Z.Y. Accumulation and depuration of paralytic shellfish poisoning toxins in the oyster Ostrea rivularis Gould-Chitosan facilitates the toxin depuration. Food Control 2013, 30, 446-452. [CrossRef]

34. Di, Y.; Aminot, Y.; Schroeder, D.C.; Readman, J.W.; Jha, A.N. Integrated biological responses and tissue-specific expression of p53 and ras genes in marine mussels following exposure to benzo $(\alpha)$ pyrene and $C_{60}$ fullerenes, either alone or in combination. Mutagenesis 2017, 32, 77-90. [CrossRef] [PubMed]

35. Romero-Geraldo Rde, J.; Garcia-Lagunas, N.; Hernandez-Saavedra, N.Y. Crassostrea gigas exposure to the dinoflagellate Prorocentrum lima: Histological and gene expression effects on the digestive gland. Mar. Environ. Res. 2016, 120, 93-102. [CrossRef] [PubMed]

36. Neves, R.A.F.; Santiago, T.C.; Carvalho, W.F.; Silva, E.D.S.; da Silva, P.M.; Nascimento, S.M. Impacts of the toxic benthic dinoflagellate Prorocentrum lima on the brown mussel Perna perna: Shell-valve closure response, immunology, and histopathology. Mar. Environ. Res. 2019, 146, 35-45. [CrossRef] 
37. Cuevas, N.; Zorita, I.; Costa, P.M.; Franco, J.; Larreta, J. Development of histopathological indices in the digestive gland and gonad of mussels: Integration with contamination levels and effects of confounding factors. Aquat. Toxicol. 2015, 162, 152-164. [CrossRef] [PubMed]

38. Zorita, I.; Ortiz-Zarragoitia, M.; Soto, M.; Cajaraville, M.P. Biomarkers in mussels from a copper site gradient (Visnes, Norway): An integrated biochemical, histochemical and histological study. Aquat. Toxicol. 2006, 78, S109-S116. [CrossRef] [PubMed]

39. Carella, F.; Sardo, A.; Mangoni, O.; Di Cioccio, D.; Urciuolo, G.; De Vico, G.; Zingone, A. Quantitative histopathology of the Mediterranean mussel (Mytilus galloprovincialis L.) exposed to the harmful dinoflagellate Ostreopsis cf. ovata. J. Invertebr. Pathol. 2015, 127, 130-140. [CrossRef]

40. Nelson, D.R.; Koymans, L.; Kamataki, T.; Stegeman, J.J.; Fey-ereisen, R.; Waxman, D.J.; Waterman, M.R.; Gotoh, O.; Coon, M.J.; Estabrook, R.W.; et al. P450 superfamily: Update on new sequences, genemapping, accession numbers and nomenclature. Pharmacogenet. Genom. 1996, 6, 1-42. [CrossRef] [PubMed]

41. Ferron, P.J.; Hogeveen, K.; De Sousa, G.; Rahmani, R.; Dubreil, E.; Fessard, V.; Le Hegarat, L. Modulation of CYP3A4 activity alters the cytotoxicity of lipophilic phycotoxins in human hepatic HepaRG cells. Toxicol. In Vitro 2016, 33, 136-146. [CrossRef]

42. Cubero-Leon, E.; Puinean, A.M.; Labadie, P.; Ciocan, C.; Itoh, N.; Kishida, M.; Osada, M.; Minier, C.; Hill, E.M.; Rotchell, J.M. Two CYP3A-like genes in the marine mussel Mytilus edulis: mRNA expression modulation following short-term exposure to endocrine disruptors. Mar. Environ. Res. 2012, 74, 32-39. [CrossRef]

43. Kumagai, T.; Suzuki, H.; Sasaki, T.; Sakaguchi, S.; Miyairi, S.; Yamazoe, Y.; Nagata, K. Polycyclic aromatic hydrocarbons activate CYP3A4 gene transcription through human pregnane X receptor. Drug Metab. Pharmacokinet. 2012, 27, 200-206. [CrossRef]

44. Ciolino, H.P.; Daschner, P.J.; Wang, T.Y.; Yeh, G.C. Effect of curcumin on the aryl hydrocarbon receptor and cytochrome P450 1A1 in MCF-7 human breast carcinoma cells. Biochem. Pharmacol. 1998, 56, 197-206. [CrossRef]

45. Rinaldi, A.L.; Morse, M.A.; Fields, H.W.; Rothas, D.A.; Pei, P.; Rodrigo, K.A.; Renner, R.J.; Mallery, S.R. Curcumin activates the aryl hydrocarbon receptor yet significantly inhibits (-)-benzo(a)pyrene-7R-trans-7,8-dihydrodiol bioactivation in oral squamous cell carcinoma cells and oral mucosa. Cancer Res. 2002, 62, 5451-5456.

46. Busbee, P.B.; Rouse, M.; Nagarkatti, M.; Nagarkatti, P.S. Use of natural AhR ligands as potential therapeutic modalities against inflammatory disorders. Nutr. Rev. 2013, 71, 353-369. [CrossRef] [PubMed]

47. Schug, T.T.; Berry, D.C.; Shaw, N.S.; Travis, S.N.; Noy, N. Opposing effects of retinoic acid on cell growth result from alternate activation of two different nuclear receptors. Cell 2007, 129, 723-733. [CrossRef]

48. Yu, M.; Chen, J.; Bao, Y.; Li, J. Genomic analysis of NF-kB signaling pathway reveals its complexity in Crassostrea gigas. Fish. Shellfish Immunol. 2018, 72, 510-518. [CrossRef] [PubMed]

49. Zhao, Y.; Li, D.; Zhang, Z.; Pan, L. In vitro recombinant yeast assay reveals the binding of 2,3,7,8-tetrachlorodibenzo-p-dioxin (TCDD) and aryl hydrocarbon receptor (AhR) from scallop Chlamys farreri. Toxicol. In Vitro 2019, 59, 64-69. [CrossRef]

50. Fonseca, E.S.S.; Ruivo, R.; Machado, A.M.; Conrado, F.; Tay, B.H.; Venkatesh, B.; Santos, M.M.; Castro, L.F.C. Evolutionary plasticity in detoxification gene modules: The preservation and loss of the pregnane $\mathrm{X}$ receptor in chondrichthyes lineages. Int. J. Mol. Sci. 2019, 20, 2331. [CrossRef] [PubMed]

51. Wang, S.; Chen, J.; Li, Z.; Wang, Y.; Fu, B.; Han, X.; Zheng, L. Cultivation of the benthic microalga Prorocentrum lima for the production of diarrhetic shellfish poisoning toxins in a vertical flat photobioreactor. Bioresour. Technol. 2015, 179, 243-248. [CrossRef]

52. Chen, J.; Wang, Y.; Pan, L.; Shen, H.; Fu, D.; Fu, B.; Sun, C.; Zheng, L. Separation and purification of two minor typical diarrhetic shellfish poisoning toxins from harmful marine microalgae via combined liquid chromatography with mass spectrometric detection. J. Sep. Sci. 2017, 40, 2906-2913. [CrossRef] [PubMed]

53. Danielli, N.M.; Trevisan, R.; Mello, D.F.; Fischer, K.; Deconto, V.S.; da Silva Acosta, D.; Bianchini, A.; Bainy, A.C.; Dafre, A.L. Upregulating Nrf2-dependent antioxidant defenses in Pacific oysters Crassostrea gigas: Investigating the Nrf2/Keap1 pathway in bivalves. Comp. Biochem. Physiol. C Toxicol. Pharmacol. 2017, 195, 16-26. [CrossRef] [PubMed]

54. Bauder, A.G.; Cembella, A.D.; Bricelj, V.M.; Quilliam, M.A. Uptake and fate of diarrhetic shellfish poisoning toxins from the dinoflagellate Prorocentrum lima in the bay scallop Argopecten irradians. Mar. Ecol. Prog. Ser. 2001, 213, 39-52. [CrossRef]

55. Fang, L.; Yao, X.; Wang, L.; Li, J. Solid-phase extraction-based ultra-sensitive detection of four lipophilic marine biotoxins in bivalves by high-performance liquid chromatography-tandem mass spectrometry. J. Chromatogr. Sci. 2015, 53, 373-379. [CrossRef]

56. Vandesompele, J.; De Preter, K.; Pattyn, F.; Poppe, B.; Van Roy, N.; De Paepe, A.; Speleman, F. Accurate normalization of real-time quantitative RT-PCR data by geometric averaging of multiple internal control genes. Genome Biol. 2002, 3, research0034.0031. [CrossRef]

57. Andersen, C.L.; Jensen, J.L.; Ørntoft, T.F. Normalization of real-time quantitative reverse transcription-PCR data: A model-based variance estimation approach to identify genes suited for normalization, applied to bladder and colon cancer data sets. Cancer Res. 2004, 64, 5245-5250. [CrossRef]

58. Pfaffl, M.W. A new mathematical model for relative quantification in real-time RT-PCR. Nucleic Acids Res. 2001, 29, e45. [CrossRef] [PubMed]

59. Derveaux, S.; Vandesompele, J.; Hellemans, J. How to do successful gene expression analysis using real-time PCR. Methods 2010, 50, 227-230. [CrossRef] [PubMed] 